\title{
SPAM1 Gene
}

National Cancer Institute

\section{Source}

National Cancer Institute. SPAM1 Gene. NCI Thesaurus. Code C26504.

This gene plays a role in the modulation of cell adhesion of spermatozoa. 